\title{
Retraction Note to: Coffee component hydroxyl hydroquinone (HHQ) as a putative ligand for PPAR gamma and implications in breast cancer
}

\author{
Babita Shashni ${ }^{1}$, Karun Sharma ${ }^{1}$, Rumani Singh², Kishore R. Sakharkar ${ }^{3}$, Sarinder K. Dhillon ${ }^{4}$, \\ Yukio Nagasaki ${ }^{5,6,7}$ and Meena K. Sakharkar ${ }^{1,8,9^{*}}$
}

\section{Retraction Note to: BMC Genomics 14, S6 (2013) \\ https://doi.org/10.1186/1471-2164-14-S5-S6}

The Editor is retracting this article because of significant overlap of text with [1] and [2]. Babita Shashni agrees with this retraction. Yukio Nagasaki and Meena K Sakharkar do not agree with this retraction. Karun Sharma, Kishore R Sakharkar and Sarinder K Dhillon have not responded to correspondence from the Editor about this retraction. The Editor was not able to obtain a current email address for Rumani Singh.
Published online: 14 February 2022

\section{References}

1. Pelicano H, Carney D, Huanga P. ROS stress in cancer cells and therapeutic implications. Drug Resistance Updates. 2004;7(2):97-110.

2. Shashni B, Sakharkar KR, Nagasaki Y, Sakharkar MK. Glycolytic enzymes PGK1 and PKM2 as novel transcriptional targets of PPARY in breast cancer pathophysiology. Journal of Drug Targeting. 2013;21(2):161-74.

\begin{abstract}
Author details
${ }^{1}$ Graduate School of Life and Environmental Sciences, University of Tsukuba, Tsukuba, Ibaraki, Japan. ${ }^{2}$ AIST, Tsukuba, Japan. ${ }^{3}$ OmicsVista, Singapore, Singapore. ${ }^{4}$ Institute of Biological Sciences, Faculty of Science, University Malaya, Kuala Lumpur, Malaysia. ${ }^{5}$ Department of Materials Sciences, Graduate School of Pure and Applied Sciences, University of Tsukuba, Ibaraki, Japan. ${ }^{6}$ Master's School of Medical Sciences, Graduate School of Comprehensive Human Sciences, University of Tsukuba, Ibaraki, Japan. ${ }^{7}$ Satellite Laboratory, International Center for Materials Nanoarchitectonics (WPI-MANA), National Institute for Materials Science (NIMS), University of Tsukuba, Ibaraki, Japan. ${ }^{8}$ Department of Biotechnology, University of Pune, Pune, India. ${ }^{9}$ Drug Discovery and Development Research Group, College of Pharmacy and Nutrition, University of Saskatchewan, Saskatoon, Canada.
\end{abstract}

The original article can be found online at https://doi.org/10.1186/1471-216414-S5-S6

*Correspondence: msakharkar@gmail.com

${ }^{9}$ Drug Discovery and Development Research Group, College of Pharmacy

and Nutrition, University of Saskatchewan, Saskatoon, Canada

Full list of author information is available at the end of the article

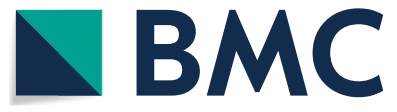

(O) The Author(s) 2022. Open Access This article is licensed under a Creative Commons Attribution 4.0 International License, which permits use, sharing, adaptation, distribution and reproduction in any medium or format, as long as you give appropriate credit to the original author(s) and the source, provide a link to the Creative Commons licence, and indicate if changes were made. The images or other third party material in this article are included in the article's Creative Commons licence, unless indicated otherwise in a credit line to the material. If material is not included in the article's Creative Commons licence and your intended use is not permitted by statutory regulation or exceeds the permitted use, you will need to obtain permission directly from the copyright holder. To view a copy of this licence, visit http://creativecommons.org/licenses/by/4.0/. The Creative Commons Public Domain Dedication waiver (http://creativeco mmons.org/publicdomain/zero/1.0/) applies to the data made available in this article, unless otherwise stated in a credit line to the data. 